\title{
Kvalita aktívnej hmoty a segmentálna distribúcia tekutín v tele ako predpoklad výkonu u elitných basketbalistiek
}

\section{Active mass quality and segmental distribution of body fluids as a precondition for performance in top-performance female basketball players}

\author{
Lucia Malá, Tomáš Malý, František Zahálka, Jaroslav Teplan, Aleš Kaplan, \\ Fakulta tělesné výchovy a sportu Karlovy univerzity Praha
}

\begin{abstract}
Abstrakt
Príspevok prezentuje kvalitu aktívnej hmoty (netuková hmota, svalová hmota) a segmentálnu distribúciu tekutín v tele ako predpoklad výkonu u vrcholových basketbalistiek, strieborných medailistiek Majstrovstiev sveta 2010. Získané dáta preukázali úroven̆ netukovej hmoty $(60,96 \pm 5,35 \mathrm{~kg})$ a svalovej hmoty $(57,07 \pm 5,0 \mathrm{~kg})$ na úrovni elitných športovcov. Tuková hmota preukázala nižšie percentuálne zastúpenie ako je dostupnou

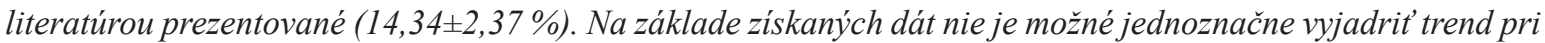
zastúpení u jednotlivých hráčskych postov. Segmentálne rozloženie tekutín preukázalo asymetriu v prospech dominantnej končatiny pri horných končatinách $(p<0,01)$, čo indikuje nevyhnutnost' realizácie cvičeni pre kompenzáciu zisteného bilaterálneho deficitu. V závere autori diskutujú o potrebe kontinuálneho sledovania zmien kvality telesného zloženia $v$ zmysle pozorovania jednotlivých zložiek vody resp. priamo a nepriamo meratelných parametrov pri bioimpedančnom meraní.
\end{abstract}

\begin{abstract}
The article presents active mass quality (fat free mass, muscle mass) and segmental distribution of body fluids as a prerequisite of performance in elite female basketball players, silvermedallists at 2010 World Championship. The collected data indicated the level of fat free mass $(60.96 \pm 5.35 \mathrm{~kg})$ and muscle mass $(57.07 \pm 5.0 \mathrm{~kg})$ at the level of elite athletes. Fat mass showed lower percentage proportion than it is presented by available literature (14.34 $2.37 \%$ ). Based on the gained data, it is not possible to definitely express a trend in proportion for individual playing positions. Segmental distribution of body fluids revealed a symmetry in favour of a dominant upper limb $(p<0.01)$, whichindicatetheneed to perform exercises in order to compensate the detected bilateral deficit. In conclusion, the authors discuss the necessity of continual monitoring changes in body composition quality in terms of monitoring individual components of water or directly and indirectly measurable parameters in bioimpedance measurement, respectively.
\end{abstract}

Kl'účové slová: telesné zloženie, netuková hmota, svalová hmota, tuková hmota, intracelulárna tekutina

Key words: body composition, fat free mass, muscle mass, fat mass, intracellular water

Tento príspevok bol podporený GAČR P407/11/P784, MSM 0021620864, PRVOUK P38a SVV 2013-267603.

\section{ÚVOD}

Výkon v basketbale je súhrou viacerých komponentov. Z motorického pohl'adu vzaté si dynamický priebeh hry a rýchla zmena herných situácií vyžadujú vysokú úroveň rýchlostných, silových schopností a špecifickej vytrvalosti, a teda výborné telesné predispozície $\mathrm{k}$ týmto pohybovým schopnostiam. Vysoká úroveň fyzickej zdatnosti je prezentovaná ako jeden zo základných faktorov vedúcich k úspešnosti družstva (Sporiš, Vuleta, Vuleta\&Milanović, 2010). Jedným z dôležitých indikátorov zdatnosti športovca (Warner, Fornetti, Jallo, \&Pivarnik, 2004) a predispozícií pre optimálny výkon je sledovanie telesného zloženia, v zmysle zaznamenania 
nadmerného množstva adipózneho tkaniva ako nevyužívanej hmoty (Reilly, 1996) a aktívnej hmoty prispievajúcej k zvýšeniu predpokladov produkcie explozívnej sily dôležitej pre vysoko intenzívnu pohybovú činnost' športovca (cyklickú, i acyklickú resp. statickú a dynamickú svalovú kontrakciu).

Dostupná literatúra zdôrazňuje rozdielnost' telesného zloženia a celkovej morfológie medzi elitnými športovcami rôznych športových odvetví (Smith\&Thomas, 1991; Gualdi-Russo\&Zaccagni, 1992; Loko, Aule, Sikkut, Ereline\&Viru,2000). Vedecké štúdie predkladajú súvislost' antropometrických parametrov a telesného zloženia s konkrétnou rolou v športovej hre (Ackland, Schreiner\&Kerr, 1997; Carter, Ackland, Kerr\&Stapff, 2005; Delextrat\&Cohen, 2009; Hasan, Rahaman, Cable\&Reilly, 2007; Sedano, Vaeyens, Philippaerts, Redondo\&Cuadrado, 2009; Gualdi - Russo\&Zaccagni, 2001; Malousaris, Bergeles, Barzouka, Bayios, Nassis\&Koskolou,2008). Bloomfield, Ackland a Elliott (1994) zdôraznili výhodu telesnej výšky a dížky končatín pri vyvinutí dostatočnej svalovej sily s nadväznost’ou na výkon v basketbale. Carbuhn, Fernandez, Bragg a Green (2010) poukázali na možnost' sledovania zmien telesného zloženia v priebehu ročného tréningového cyklu. Autori zistili u univerzitných hráčok basketbalu signifikantné zmeny tukovej hmoty, hustoty kostného tkaniva a obsahu kostných minerálov v priebehu periodizácie tréningového cyklu. Acklandet al. (1997) longitudiálne sledovali morfologické zmeny v rámci jednotlivých tímov pol'skej národnej reprezentácie.

Monitorovanie zmien $\mathrm{v}$ oblasti periodizácie športového tréningu v jednotlivých obdobiach počas sezóny je vnímané ako spätná väzba k riadeniu tréningu (Carbuhnet al., 2010).

Monitorovanie telesného zloženia je odporúčané ako možnost' predchádzat' negatívnym dopadom nesprávnej nutrície, stravovacích návykov a doplnkov stravy u športovkýň s prípadnými následkami (Fruth, Morgan, Darby\&Tobar, 2008). Marrina Bampouras(1998) uvádzajú vo výskume (n = 371, športovkýn̆ - basketbal, volejbal, softbal, sút'aže NCAA v USA), že až 29 \% hráčok používa prostriedky k úprave telesnej hmotnosti, pričom nutrícia je jedným z dôležitých faktorov ovplyvňujúcich optimálne telesné zloženie ako predispozíciu pre výkon.

Z hladiska somatotypu a telesného zloženia ako predpokladov pre výkon v basketbale sú vhodní jedinci s vysokou telesnou výškou, s dlhými končatinami, s vysokým zastúpením netukovej hmoty a nízkym zastúpením tukovej hmoty. Dostupné štúdie dokladujú telesné zloženie primerané zástupkyniam vrcholového športu, tj. vysoké zastúpenie netukovej hmoty so vzt’ahom k výkonu, ku konkrétnym činnostiam jednotlivcov resp. v komparácii s inými kolektívnymi hrami (Bayios, Bergeles, Apostolidis, Noutsos\&Koskolou, 2006; Malá, Malý, Zahálka\&Bunc,2010; Fleck, 1983; Gholami\&Rad, 2010; Hasanet al., 2007), nízke zastúpenie tukovej hmoty a zmeny týchto zložiek v priebehu periodizácie prípravy (Fruthet al., 2008; Carbuhnet al., 2010; Malá, Malý, Zahálka, Tůma\&Bunc,2011). Ciel'om nášho príspevku je zamerat' sa na úroveň parametrov indikujúcich kvalitu aktívnej hmoty a na distribúciu tekutín $\mathrm{v}$ jednotlivých segmentoch s indikáciou asymetrie ako predispozíciu pre výkon u elitného ženského basketbalového tímu, strieborných medailistiek Majstrovstiev sveta 2010.

\section{METODIKA}

Charakteristika výskumného súboru

Výskumný súbor tvorila ženská reprezentácia basketbalistiek $(\mathrm{n}=14)$, strieborných medailistiek Majstrovstiev sveta 2010. Tréningová prax bola minimálne 10 rokov, jednalo sa teda o špecifickú skupinu s vysokým podielom riadenej pohybovej aktivity. Základné somatometrické charakteristiky výskumného súboru prezentuje tab. 1.

Tab. 1: somatometrické charakteristiky výskumného súboru

Legenda:

\begin{tabular}{|l|c|c|c|c|c|}
\hline & Minimum & Maximum & Priemer & $\begin{array}{c}\text { Smerodajná } \\
\text { odchýlka }\end{array}$ & $\begin{array}{c}\text { Stredná } \\
\text { chyba } \\
\text { priemeru }\end{array}$ \\
\hline Vek (roky) & 19,00 & 32,00 & 25,86 & 4,20 & 1,12 \\
\hline $\begin{array}{l}\text { Telesná výška } \\
(\mathrm{cm})\end{array}$ & 169,00 & 198,00 & 185,79 & 8,99 & 2,40 \\
\hline $\begin{array}{l}\text { Telesná } \\
\text { hmotnost' (kg) }\end{array}$ & 64,00 & 90,00 & 76,64 & 7,82 & 2,09 \\
\hline BMI (kg.cm $\left.{ }^{-2}\right)$ & 20,30 & 25,70 & 22,19 & 1,55 & 0,42 \\
\hline
\end{tabular}

BMI - Body Mass Index (index rizika ohrozenia zdravia podl’a Svetovej zdravotníckej organizácie) 


\section{Spôsob získavania výskumných dát}

Dáta identifikujúce telesné zloženie vrcholových basketbalistiek sme zaznamenali za rovnakých podmienok, v ranných hodinách, hráčky neužili žiadne medikamenty. Z hl'adiska periodizácie ročného tréningového plánu sme sa nachádzali na začiatku sút’ǎného obdobia. Pred samotným meraním sme zistili aktuálnu telesnú výšku hráčok v stoji s presnost'ou na $1 \mathrm{~mm}$ pomocou digitálneho staciometra (SECA 242, Hamburg, Germany). Pre stanovenie celotelovej bioimpedancie sme použili multifrekvenčnýbioimpedančnýanalyzér In Body 3.0 (Biospace), ktorý pracuje na štyroch frekvenciách $(1,5,50$ a $100 \mathrm{kHz})$ a funguje na princípe osembodových tetrapolárnych dotykových bodov. Vlastné meranie trvalo približne $120 \mathrm{~s}$, aktuálnu telesnú hmotnost' zaznamenal samotný analyzér s presnost'ou na $1 \mathrm{~g}$. Boli zachované štandardizované podmienky bioimpedančného merania (Kyle, Bosaeus, DeLorenzo, Deurenberg, Elia, Manuel Gomez, Heitmann, Kent - Smith, Melchior, Pirlich, Scharfetter, Schols\&Pichard, 2004).Na základe získaných hodnôt sme zistili aktuálne zloženie tela zástupkýň tímu. Sledovali sme absolútne a relatívne množstvo netukovej hmoty, absolútne a relatívne množstvo svalovej hmoty, percentuálne zastúpenie tukovej hmoty u hráčok, celkovú telesnú vodu s rozlíšením extracelulárnej a intracelulárnej tekutiny a segmentálnu distribúciu tekutín v tele hráčok.

\section{Spôsob spracovania dát}

Pri prepočte nepriamo odhadnutých parametrov identifikujúcich telesné zloženie sme vychádzali z predikčných rovníc softwéru pre danú vekovú skupinu (Biospace). Pre zistenie významnosti rozdielov medzi párovými končatinami sme použili parametrický $\mathrm{t}$ - test pre závislé skupiny. Distribúciu normality dát sme overili Shapiro - Wilkovým testom. Pre zistenie miery asociácie vybraných parametrov sme použili Pearsonovú korelačnú analýzu. Za vecne (prakticky) významný rozdiel medzi porovnávaním objemu tekutín u párových končatín sme považovali $2 \%$ rozdiel.

\section{VÝSLEDKY}

V sledovanom súbore sme zaznamenali priemernú hodnotu celkovej vody v tele 44,93 $\pm 1,05$ 1. Priemerná hodnota intracelulárnej tekutiny z toho bola $30,51 \pm 0,661$ ( $67,9 \neg \neg \%$ z celkovej vody v tele). Priemerná hodnota

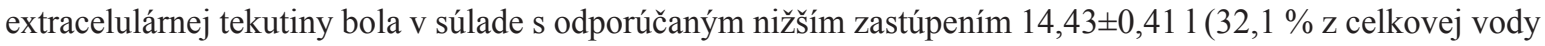
$\mathrm{v}$ tele).

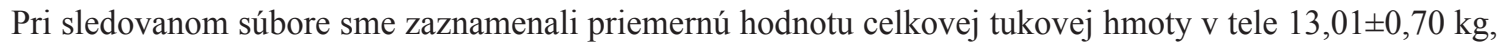

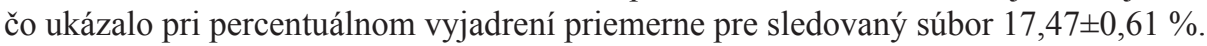

Netuková hmota činila pre celý súbor priemerne $60,9 \pm 1,38 \mathrm{~kg}, \mathrm{v}$ relatívnom vyjadrení $0,80 \pm 0,08$. Svalová

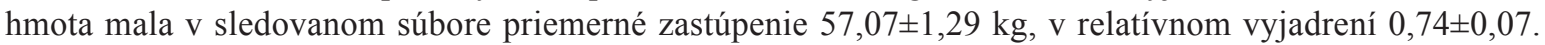
Rozloženie tekutín na jednotlivých segmentoch tela preukázalo vyššie hodnoty pri porovnaní s hodnotami prezentovanými softwérom pre všeobecnú populáciu príslušnej vekovej kategórie (obr. 2). Jednotlivé priemerné i okrajové hodnoty prezentuje tabul'ka 2.

Tab. 2: Profil telesného zloženia vrcholových basketbalistiek pomocou metódy InBody 3.0

\begin{tabular}{|l|c|c|c|c|c|c|}
\hline \multirow{2}{*}{ Parameter } & \multirow{2}{*}{$\begin{array}{c}\text { Min. } \\
\text { hodnota }\end{array}$} & $\begin{array}{c}\text { Max. } \\
\text { hodnot }\end{array}$ & \multicolumn{2}{c|}{ Priemer } & Smerodajná & \\
\cline { 4 - 6 } & & Hodnota & $\begin{array}{c}\text { Standardná } \\
\text { chyba }\end{array}$ & Variancia \\
odchýlka & & \\
\hline Intracelulárna tekutina (l) & 25,80 & 33,10 & 30,51 & 0,66 & 2,55 & 6,53 \\
Extracelulárna tekutina (l) & 12,00 & 16,80 & 14,43 & 0,41 & 1,61 & 2,58 \\
Tuková hmota (kg) & 9,10 & 19,30 & 13,01 & 0,70 & 2,69 & 7,26 \\
Celková voda v tele (l) & 37,90 & 49,80 & 44,93 & 1,05 & 4,06 & 16,47 \\
Svalová hmota (kg) & 48,20 & 63,10 & 57,07 & 1,29 & 5,00 & 25,02 \\
Svalová hmota - relatívna & 0,63 & 0,82 & 0,74 & 0,01 & 0,07 & 0,01 \\
Netuková hmota (kg) & 51,50 & 67,20 & 60,96 & 1,38 & 5,35 & 28,62 \\
Netuková hmota - & 0,67 & 0,88 & 0,80 & 0,01 & 0,08 & 0,01 \\
relatívna & & & & & & \\
Tuková hmota (\%) & 13,60 & 22,70 & 17,47 & 0,61 & 2,37 & 5,64 \\
PR (l) & 2,02 & 2,88 & 2,56 & 0,07 & 0,27 & 0,07 \\
LR (l) & 2,02 & 2,85 & 2,53 & 0,07 & 0,27 & 0,07 \\
T (l) & 17,60 & 22,70 & 20,67 & 0,44 & 1,70 & 2,88 \\
PN (l) & 6,46 & 9,17 & 7,74 & 0,21 & 0,83 & 0,69 \\
LN (l) & 6,41 & 9,21 & 7,75 & 0,22 & 0,86 & 0,75 \\
\hline
\end{tabular}


Legenda:

PR - objem tekutín v pravej paži(l) $\quad$ PN - objem tekutín v pravej dolnej končatine (l)

LR - objem tekutín v l'avej paži(l) LN - objem tekutín v l'avej dolnej končatine (l)

$\mathrm{T}$ - objem tekutín v trupe (1)

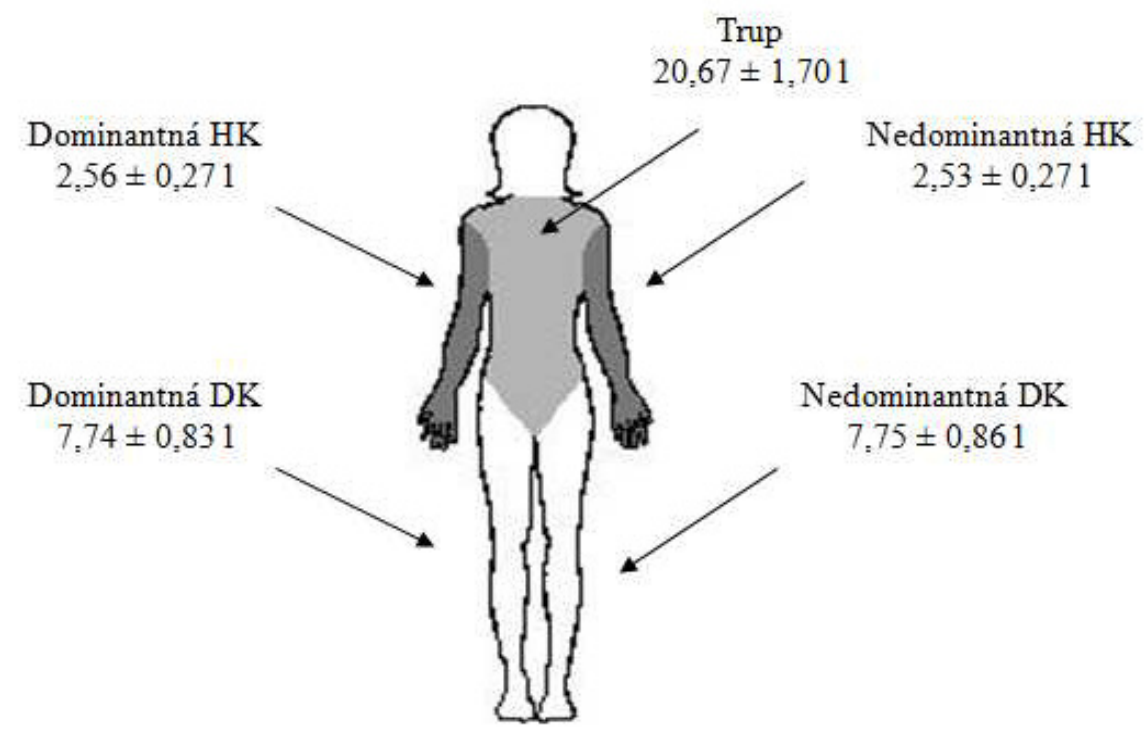

Obr. 1 Segmentálne rozloženie tekutín u vrcholových basketbalistiek

Legenda:

HK - horná končatina

DK - dolná končatina

Významnost’ rozdielu pri sledovaní rozloženia tekutín na končatinách bola zaznamenaná len pri horných končatinách $(t(14)=2,47 ; \mathrm{p}<0,05)$. Na dolných končatinách sme zistili rovnomerné zastúpenie objemu tekutín $\mathrm{s}$ nevýznamným rozdielom medzi sledovanými segmentami $(\mathrm{t} 14)=-0,862 ; \mathrm{p}>0,05)$, tab. 3 .

Tab. 3 Významnost' rozdielu segmentálneho rozloženia tekutín u vrcholových basketbalistiek

\begin{tabular}{|c|c|c|c|c|c|c|c|c|}
\hline \multirow{3}{*}{ Parameter } & \multicolumn{5}{|c|}{ Rozdiel priemerov porovnávaných skupín } & \multirow{3}{*}{$\begin{array}{c}c t- \\
\text { testovacia } \\
\text { štatistika }\end{array}$} & \multirow{3}{*}{$\begin{array}{l}\text { Stupne } \\
\text { vol'nosti }\end{array}$} & \multirow{3}{*}{$\begin{array}{c}\text { Významnost' } \\
\text { rozdielu }\end{array}$} \\
\hline & \multirow[t]{2}{*}{ Priemer } & \multirow{2}{*}{$\begin{array}{l}\text { Smerodajná } \\
\text { odchýlka }\end{array}$} & \multirow{2}{*}{$\begin{array}{c}\text { Stredná chyba } \\
\text { priemeru }\end{array}$} & \multicolumn{2}{|c|}{$\begin{array}{c}\text { 95\% konfidenčný } \\
\text { interval }\end{array}$} & & & \\
\hline & & & & Dolný & Horný & & & \\
\hline$\overline{P R}-\mathrm{LR}$ & 0,03 & 0,04 & 0,01 & 0,004 & 0,051 & $2,471^{*}$ & 14 & ,027 \\
\hline $\mathrm{PN}-\mathrm{LN}$ & $-0,02$ & 0,07 & 0,02 & $-0,053$ & 0,023 &,- 862 & 14 & ,403 \\
\hline
\end{tabular}

Legenda:

PR - objem tekutín v pravej paži (l)

PN- objem tekutín v pravej dolnej končatine (1)

LR - objem tekutín v l'avej paži (l)

LN - objem tekutín v l'avej dolnej končatine (l)

$*-\mathrm{p}<0,05$

\section{DISKUSIA}

Telesné zloženie ako prediktorpohybového výkonu v basketbale je orientované na žiaducu aktívnu zložku a nežiaducu neaktívnu zložku. Podl'a DeLorenzoet al. (1997) sú aktívna zložka a jej časti (netuková hmota, vnútrobunečná hmota, svalová hmota) definované ako celková hmota buniek tela. Netuková hmota činila v sledovanom súbore 79,54 \% z priemernej telesnej hmotnosti (tab. 2). Zaznamenaná hodnota je vyššia v porovnaní s hodnotami netukovej hmoty uvádzanými Carbuhnet al. (2010), ktorí prezentujú u vrcholových baketbalistiek ( $\mathrm{n}=10$, univerzitné hráčky, $20 \pm 1,0$ rokov, $180,1 \pm 8,9 \mathrm{~cm}, 76,9 \pm 9,0 \mathrm{~kg}$ ) absolútnu hodnotu netukovej 
hmoty 55,8 $\pm 5,8$ kg. Komparácia je však zat’ažená porovnávaním absolútnych hodnôt (vyššia telesná výška českých hráčok) a rozdielnost'ou použitej metodiky. Intraindividuálne porovnanie relatívnych hodnôt preukázalo u nami sledovaných hráčok hodnoty netukovej hmoty na úrovni elitných športovcov (Bayioset al., 2006;Fleck, 1983; Gholami\&Rad, 2010; Hasanet al., 2007; Malá et al., 2010, Malá et al., 2011; Malý Malá, Zahálka, Baláš\&Čada, 2011). Pri jednotlivých hráčskych postoch získané dáta nepreukázali jednoznačný trend v zastúpení netukovej hmoty. Najvyššiu hodnotu sme zaznamenali u rozohrávačky a pivotky $(0,88)$. Najnižšiu hodnotu sme zaznamenali u krídla $(0,67)$.

Aktívne sa na pohybe podiel'ajúca zložka netukovej hmoty je vnímaná ako súčet hmotnosti všetkých buniek, ktoré utilizujú kyslík, preto je možné označit' ju ako kvalitatívny parameter pre posúdenie svalovej hmoty. Svalová hmota činila priemerne $74,47 \%$ priemernej telesnej hmotnosti (tab. 2). V zmysle percentuálneho podielu buniek v netukovej hmote ako indikátora individuálneho stavu výživy a trénovanosti môžeme konštatovat' hodnoty prislúchajúce vrcholovému športu (Dörhöfer\&Pirlich, 2007; Malá et al., 2008). Pri intraindividuálnom hodnotení nie je možné vyjadrit' jednoznačne trend zastúpenia u jednotlivých herných postov. Takmer u všetkých reprezentantiek sme zaznamenali hodnoty odhadnutej svalovej hmoty približujúce sa k odporúčanému zastúpeniu s výnimkou jedinej pivotky $(0,63)$. Vyšší rozdiel pripisujeme oneskoreným nástupom pivotky na kontinuálnu prípravu na Majstrovstvá sveta, z dôvodu klubových povinností. Najvyššiu hodnotu svalovej hmoty sme zaznamenali v súlade s najvyššou zaznamenanou relatívnou hodnotou netukovej hmoty u krídla $(0,82)$.

Zaznamenané priemerné percentuálne zastúpenie neaktívnej hmoty (tab. 2) je porovnatel'né s navrhovanými hodnotami tukového tkaniva pre športujúce ženy (Lohman, 1992) v rozmedzí $12-16 \%$ v závislosti od športu. Dostupná literatúra uvádza však u basketbalistiek vyššie hodnoty, kde Carbuhnet al. (2010) zistili zastúpenie

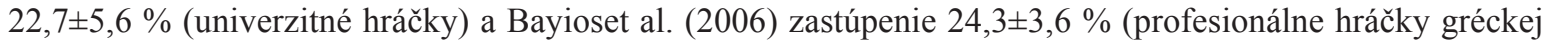
I. a II. ligy, $\mathrm{n}=133,23,6 \pm 4,5$ rokov, $174,7 \pm 7,8 \mathrm{~cm}, 71,5 \pm 10,1 \mathrm{~kg}$ ). Dostupná literatúra (Bayioset al., 2006; Leone, Lariviere\&Comtois, 2002) zdôrazňuje variabilitu telesného zloženia medzi jednotlivými tímami športových hier. Bayioset al. (2006) preukázali u basketbalistiek signifikantne vyššie hodnoty tukovej hmoty $(\mathrm{p}<0,05)$ ako skupina volejbalistiek ( $\mathrm{n}=163$, tuková hmota $=23,4 \pm 2,8 \%)$ a signifikantne nižšie hodnoty tukovej hmoty $(\mathrm{p}<0,001)$ v porovnaní so skupinou hádzanárok $(\mathrm{n}=222$, tuková hmota $=25,9 \pm 3,3 \%)$. Dôvodom rozdielnosti môže byt' výber metodiky pre identifikáciu telesného zloženia a predikčnej rovnice pre prepočet tukovej hmoty. Ani neaktívna hmota nepreukázala trend v zastúpení u jednotlivých hráčskych postov. Najvyššie zastúpenie sme zaznamenali u krídla (22,7 \%), najnižšiu hodnotu u rozohrávačky $(13,6 \%)$.

Pri sledovaní segmentálneho rozloženia objemu tekutín na končatinách a trupe (obr. 1) sme zaznamenali signifikantný rozdiel len na horných končatinách $(\mathrm{p}<0,01 ;$ tab. 3). Asymetria bola zistená v prospech dominantnej hornej končatiny. Vniknutý rozdiel indikuje nevyhnutnost’ realizácie cvičení pre kompenzáciu zisteného bilaterálneho deficitu.

Netuková hmota spolu s prezentovanou svalovou hmotou ako parameter s bližším vzt’ahom k úspešnosti $\mathrm{v}$ športe v porovnaní s tukovou hmotou je prezentovaná ako žiaduca pri prerozdelení parametrov určujúcich kvalitu telesného zloženia hráčky. Vel'kost' a podiel netukovej hmoty má i pri porovnaní s bežne meratel'nými somatometrickými parametrami úzky vzt’ah ku rôznym funkčným veličinám podiel’ajúcich sa na výkone v basketbale. Podl’a Musaiger, Ragheb\&Marzooq, 1994) nízke zastúpenie tukového tkaniva je žiaduce práve kvôli negatívnemu vzt’ahu výkonu a percentuálneho zastúpenia tukového tkaniva.Prípadné zaznamenané zmeny pomeru zastúpenia aktívnej a neaktívnej zložky, v zmysle zvýšenia netukovej hmoty, svalovej hmoty a zníženia tukovej hmoty, sú vo väčšine prípadov indikátorom zlepšenej úrovne telesného zloženia a zlepšenia svalovej kvality. Zmeny však môžu byt' spôsobené aj stratou vody v extracelulárnom priestore $(14,43 \pm 1,611 \mathrm{v}$ sledovanom súbore), pozorovatel'nom pri strate tekutín po tréningovom alebo sút'ažnom procese (následný nepriamy odhad tukovej hmoty bioimpedančnou metódou môže preukázat' zníženie). Zmeny netukovej hmoty a jej zložiek sú spôsobené jej 73 \% obsahom vody (FFM = TBW / 0.73) (Wang, Deurenberg, Wang, Pietrobelli, Baumgartner\&Heymsfield, 1999).Pri pozorovaní jednotlivých zložiek vody intracelulárna tekutina predstavovala požadované vyššie zastúpenie (tab. 2). Prípadná strata vody až dehydratácia sa následne prejaví na znížení pozornosti basketbalistiek (Baker, Conroy\&Kenney, 2007). Náhrada tekutín je z dôvodu zachovania koncentrácie a pozornosti a optimálneho prevedenia zručností v priebehu sút’aže nevyhnutná. Kontinuálnym zaznamenaním distribúcie tekutín $\mathrm{v}$ jednotlivých segmentoch tela je možné sledovat' priebežné zmeny pri kompenzácii svalových dysbalancií, prípadne pri liečení zranení hráčky. Sledovanie segmentálneho rozloženia tekutín i kvality aktívnej hmoty je potrebné realizovat' kontinuálne, počas vybraných období ročného tréningového cyklu a s následnou väzbou na dávkovanie tréningového zat’aženia a času zotavenia (Bresciani, Cuevas, Garatachea, Molinero, 
Almar, De Paz, Marquez\&Gonzalez - Gallego, 2010).

\section{ZÁVER}

Zaznamenané parametre telesného zloženia preukázali hodnoty zodpovedajúce ženskému elitnému športu. Zistené hodnoty preukázali, že aktívna zložka zaznamenaná bioimpedančnou metódou by mala u elitných hráčok dosahovat' zastúpenie $60,96 \mathrm{~kg}$ v absolútnej hodnote, v relatívnom vyjadrení $0,80 \pm 0,08$. Nami získané dáta preukázali vyššie hodnoty aktívnej zložky a nižšie hodnoty neaktívnej zložky pri porovnaní so štúdiami, v ktorých bolo sledované telesné zloženie pomocou bioimpedančnej analýzy u elitných hráčok. V interindividuálnych porovnaniach nie je možné jednoznačne vyjadrit' rozdiely trend pri zastúpení u jednotlivých hráčskych postov. Predkladané dáta môžu slúžit' ako štandard pre komparáciu kvality telesného zloženia u basketbalistiek rôznych hráčskych úrovní. Preukázaná asymetria zastúpenie tekutín na horných končatinách je prejavom maladaptácie na špecifické zat'aženie u hráčok. Tieto rozdiely by mali byt' v tréningovej praxi nielen objektivizované, ale najmä vhodným tréningom kompenzované. Unilaterálne silové cvičenia, by tak mali byt' vo vyššej miere zastúpené na končatinu u ktorej bol zistený deficit.

\section{LITERATÚRA}

Ackland, T.R., Schreiner, A.B. \& Kerr, D.A. (1997). Absolute size and proporcionality charcteristics of Word Championship finale basketball players. Journal of Sports Science, 15, 485-490.

Baker, L.B., Conroy, D.E.\& Kenney, W.R. (2007). Dehydration Impairs Vigilance-Related Attention in Male Basketball Players. Medicine and Science in Sports and Exercise, 39(6), 976-83.

Bayios, I.A., Bergeles, N.K., Apostolidis, N.G.,Noutsos, K.S. \& Koskolou, M.D. (2006). Anthropometric body composition and somatotype differences of Greek elite female basketball, volleyball and handball players. J Sports Med PhysFitness, 46, 271-80.

Bloomfield, J., Ackland, T.R. \& Elliott, B.C. (1994). Applied Anatomy and Biomechanics in Sport. Melbourne: Blackwell Scienti.

Bresciani, G., Cuevas, M.J., Garatachea, N., Molinero, O., Almar, M., De Paz, J.A, Marquez, S. \& GonzalezGallego, J. (2010). Monitoring biological and psychological measures throughout an entire season in male handball players. European Journal of Sport Science, 10(6), 377-384.

Carbuhn, A.F., Fernandez, T.E., Bragg, A.F. \& Green, J.S. (2010). Sport and training influence bone and body composition in women collegiate athletes. Journal of Strength and Conditioning Association, 24(7), 1710-1717. Carter, J.E.L., Ackland, T.R., Kerr, D.A. \& Stapff, A.B.(2005).Somatotype and size of elite female basketball players. Journal of Sports Sciences, (23)10, 1057-1063.

Delextrat, A., \& Cohen, D. (2009). Strength, power, speed, and agility of women basketball players according to playing position. Journal of Strength and Conditioning Research, 23(7), 1974-1981.

Dörhöfer, R.P. \& Pirlich, M. (2007). Das BIA - Kompendium, III. Ausgabe. Data Input GmbH, Darmstadt.

Fleck, S.J. (1983). Body composition of elite American athletes. American Journal of Sports Medicine, 11, 398-403.

Fruth, J., Morgan, A., Darby, L. \& Tobar, D. (2008). Evaluation of three skinfold equations by using the bod pod as the criterion in caucasian female athletes. Journal of Exercise Physiology, 11(1), 28-37.

Gholami, M. \& Rad, L, S. (2010).Anthropometric, body composition and somatotype differences of Iranian Elite female basketball and handball players. British journal of sports medicine, 44(14), 19-20.

Gualdi-Russo, E. \& Zaccagni, L. (2001). Somatotype, role and performance in elite volleyball players. J Sports Med Phys Fitness, 41, 256-62.

Hasan, A.A., Rahaman, J.A., Cable, N.T. \& Reilly, T. (2007). Anthropometric profile of elite male handball players in Asia. Biology of Sport, 24(1), 3-12.

Kyle, U. G., Bosaeus, I., DeLorenzo, A. D., Deurenberg, P., Elia, M.,

Manuel Gomez, J., Heitmann, B.L., Kent-Smith, L., Melchior, J.C., Pirlich, M., Scharfetter,

H., Schols, A.M. \& Pichard, C. (2004). Bioelectrical impedance analysis - part II: utilization in clinical practice. Clinical Nutrition, 23(6), 1430-1453.

Loko, J., Aule, R., Sikkut, T., Ereline, J. \&Viru, A. (2000). Motor performance status in 10- to 17-year-old Estonian girls. Scandinavian Journal of Medicine and Science in Sports, 10, 109-113.

Lohman, T.G. (1992). Advances in Body Composition Assessment. Human Kinetics, Champaign. 
Leone, M. Lariviere, G. \& Comtois, A.S. (2002). Discriminant analysis of anthropometric and biomotor variables among elite adolescent female athletes in four sports. Journal of Sports Sciences, 20, 443-449.

Malá, L., Malý, T., Zahálka, F. (2008), Profil telesného zloženia juniorských reprezentantov v jude. Česká kinantropologie, 3, 94-103.

Malá, L., Malý, T., Zahálka, F. \& Bunc, V. (2010). The profile and comparison of Body composition of elite female volleyball players. Kinesiology, 42(1), 90-97.

Malá, L., Malý, T., Zahálka, F., Tůma, M. \& Bunc. V. (2011). Body composition of elite female handball players. Acta Universitatis Carolinae Kinanthropologica, 47(1), 131-140.

Malý, T., Malá, L., Zahálka, F., Baláš, J. \& Čada, M. (2011). Comparison of body Composition between two elite women's voleyball teams. Acta Universitatis Palackianae Olomucensis, 41(1), 15-22.

Malousaris, G.G., Bergeles, N.K., Barzouka, K.G., Bayios, I.A., Nassis, G.P. \& Koskolou, M.D. (2008). Somatotype, size and body composition of competitive female volleyball players. Journal of Science and Medicine in Sport, 11(3), 337-344.

Marrin, K. \& Bampouras, T.M. (2008). Anthropometric and physiological changes in elite female water polo players during a training year. Serbian Journal of Sports Sciences, 2(3), 75-83.

Musaiger A.O., Ragheb, M.A., \& G. al-Marzooq, G. (1994). Body composition of athletes in Bahrain. Br J Sp Med, 28(3), 157-159.

Piechaczek, H. (1990). Body structure of male and female basketball players. Biology of Sport, 7, 273-285.

Reilly, T. (1996) Fitness assessment. In: Science and soccer. Ed: Reilly, T. London: E. \& F. Spon. 25-50.

Sedano, S., Vaeyens, R., Philippaerts, R.M., Redondo, J.C., \& Cuadrado, G. (2009). Anthropometric and ana erobic fitness profile of elite and non-elite female soccer players. J Sports med phys fitness, 49, 387-94.

Smith, H.K. \& Thomas, S.G. (1991). Physiological characteristics of elite female basketball players. Canadian Journal of Sport Sciences, 16, 289-295.

Sporiš, G., Vuleta, D., Vuleta J.D. \& Milanović, D. (2010). Fitness Profiling in Handball: Physical and Physiological Characteristics of Elite Players. Collegium Antropologicum, 34(3), 1009-1014.

Wang, Z.M., Deurenberg, P., Wang, W., Pietrobelli, A., Baumgartner, R.N. \& Heymsfield, S.B. (1999). Hydratationoffat-fre body mass: review and critiqueof a classic body - compositionconstant. Am J ClinNutr, $69,833-841$.

Warner, E., Fornetti, W., Jallo, J. \& Pivarnik, J. (2004). A skinfold model to predict fat-free mass in female athletes. J Athl Train, 39(3), 259-262. 